\section{Summary}

The value of drug treatment in angina pectoris can be accurately assessed by using reproducible treadmill exercise under controlled conditions. A "training" period to allow patients to become completely familiar with the test is of great importance, because during this period effort tolerance usually increases irrespective of drug therapy.

The change in effort tolerance after pronethalol or propranolol, compared with placebo, was measured in 20 patients. A wide variation in response was obtained, but the mean improvement of $36 \%$ was highly significant $(P<0.001)$.

We wish to thank Dr. G. W. Hayward for permission to study patients under his care, and also the Department of Medical Illustration for preparing the figure. Part of this work was carried out while one of us (D.A.B.) was in receipt of an Aylwen Bursary. Pronethalol and propranolol were supplied by the Pharmaceutical Division of Imperial Chemical Industries Itt
REFERENCES

Abrahamsen, A. M., and Kiil, F. (1966). Brit. med. F., 1, 456.

Alleyne, G. A. O., Dickinson, C. J., Dornhorst, A. C., Fulton, K. M., Green, K. G., Hill, I. D., Hurst, P., Laurence, D. R., Pilkington, T., Prichard, B. N. C., Robinson, B., and Rosenheim, M. L. (1963). Ibid., 2, 1226.

Apthorp, G. H., Chamberlain, D. A., and Hayward, G. W. (1964). Brit. Heart $\dot{f}$., 26, 218.

Birkett, D. A., Apthorp, G. H., Chamberlain, D. A., Hayward, G. W., and Tuckwell, E. G. (1965). Brit. med. Ұ., 2, 187.

Dornhorst, A. C., and Robinson, B. F. (1962). Lancet, 2, 314.

Hamer, J., Grand ean, T., Melendez, L., and Sowton, G. E. (1964). Brit. med. F., 2, 720 .

Keelan, P. J. R. B. (1965). Ibid., 1, 897.

MacAlpin, R. N., Kattus, A. A., and Winfield, M. E. (1965). Circulation, 31, 869.

McNeill, R. S. (1964). Lancet, 2, 1101.

Muir, G. G., Chamberlain, D. A., and Tunstall Pedoc, D. (1964). Ibid., 2, 930.

Paget, G. E. (1963). Brit. med. F., 2, 1266.

Srivastava, S. C., Dewar, H. A., and Newell, D. J. (1964). Ibid., 2. 724.

\title{
Effect of Moderate Exercise on the Fibrinolytic System in Normal Young Men and Women
}

\author{
J. D. CASH, * M.B., B.SC., M.R.C.P.ED
}

Brit. med. F., 1966, 2, 502-506

There is considerable evidence to show that exercise increases plasma fibrinolysis (Biggs et al., 1947; Truelove, 1951; Fearnley and Lackner, 1955 ; Sherry et al., 1959 ; Billimoria et al., 1959 ; Ogston and Fullerton, 1961 ; Jang et al., 1964 ; Ogston and McAndrew, 1964 ; Burt et al., 1964) and that this is due to an increased level of plasminogen activator (Sawyer et al., 1960 ; Iatridis and Ferguson, 1963). Careful analysis of the results of all these workers reveals that some of their subjects responded poorly. Those who have commented on these poor responders have given tentative explanations. Biggs et al. (1947) thought increased physical fitness relevant, Sawyer et al. (1960) inappropriate timing of sample collection, whereas Iatridis and Ferguson (1963) suggested that the reason might be the failure to show the usual reaction to stress or to the production of a fibrinolytic inhibitor. It is not possible to make any valid conclusions from these studies, however, because of the variation of fibrinolytic assays and in the type of exercise used in different laboratories. Of no less importance is the fact that in most studies exercise to exhaustion was used and therefore no attempt was made to examine individual reproducibility of response.

In view of Astrup's (1956) hypothesis that there exists a delicately balanced dynamic equilibrium between coagulation and fibrinolysis, and that disequilibrium might result in atherosclerosis and thrombus formation, then the concept of a poorly reactive fibrinolytic system in a small proportion of apparently healthy young persons would be of considerable interest.

This paper describes a series of experiments in which the fibrinolytic system was studied before and after a standard moderate exercise procedure in a group of young healthy subjects.

\section{Subjects}

The subjects were 25 healthy male and 25 healthy female volunteers aged 18 to 30 years. All subjects undertook the

\footnotetext{
* From the South-east Scotland Regional Blood Transfusion Research
} Laboratories, Royal Infirmary, Edinburgh. exercise procedure on more than one occasion. Most exper1ments were repeated at weekly intervals, but a few at intervals of several months. Nine of the women, with a history of regular and trouble-free menstrual cycles, were studied at weekly intervals throughout a menstrual cycle.

\section{Materials}

Anticoagulant.-Sodium citrate B.P. $3.8 \%$.

Buffers.-(a) Barbiturate buffer. Modified veronal buffer of $p \mathrm{H} 7.4$ and ionic strength 0.15 (Owren, 1947). (b) Tris buffer. $0.15 \mathrm{M}$ solution of tris-(hydroxymethyl)-amino-methane (Koch-Light Laboratories Ltd., batch No. 11342) adjusted to pH 7.8. (c) Phosphate buffer. $0.1 \mathrm{M}$ at $\mathrm{pH}$ 7.6.

Fibrinogen.-A Blombäck and Blombäck (1957) preparation of human fibrinogen with a clottability of $97 \%$ (supplied by Kabi Pharmaceutical Company, batch No. 83164) was used. A $1.5 \mathrm{~g} . / 100 \mathrm{ml}$. solution of fibrinogen in tris buffer was stored in plastic tubes at $-20^{\circ} \mathrm{C}$. After thawing it was diluted to $0.15 \mathrm{~g} . / 100 \mathrm{ml}$. in tris buffer and used for fibrin plates.

Thrombin.-Topical thrombin (Parke Davis and Co., batch No. $03179 \mathrm{~A}$ ) was used. A solution of 50 units $/ \mathrm{ml}$. in tris buffer was prepared for fibrin plates, one of 5 units $/ \mathrm{ml}$. in barbiturate buffer for euglobulin lysis time estimations, and one of 100 units $/ \mathrm{ml}$. in physiological saline for fibrinogen estimations. All these solutions were stored at $-20^{\circ} \mathrm{C}$. in plastic tubes and used immediately after thawing.

Streptokinase. - The preparation produced by Lederle Laboratories (batch No. 2201-66) was used for plasminogen assays. It was diluted to 2,000 units $/ \mathrm{ml}$. in phosphate buffer and stored in plastic tubes at $-20^{\circ} \mathrm{C}$.

Urokinase.-The standard reference preparation $(2,400$ Plough units) produced by Leo Pharmaceuticals, Denmark (batch No. 63062) was used. Solutions of 3 units $/ \mathrm{ml}$. in tris buffer were prepared and stored at $-20^{\circ} \mathrm{C}$. in plastic tubes.

Glassware.-All glassware was siliconized by means of a $3 \%$ solution of I.C.I. M550 silicone in trichlorethylene. 


\section{Methods}

Exercise Procedure.-All experiments were carried out during the morning, after a light breakfast, in a procedure-room at $19-20^{\circ} \mathrm{C}$. Subjects abstained from smoking and excessive exercise on the morning prior to the experiment, and were required to rest, lying down, for 30 minutes before the initial venepuncture. At the end of the rest period each subject walked at 3.4 m.p.h. on a treadmill at 5 degrees elevation for a period of eight minutes. They were required to adjust their stride to 120 paces a minute. Pulse rates immediately before and after the exercise were recorded on an electrocardiograph.

Blood Sampling and Centrifugation.-From a vein in the cubital fossa $9 \mathrm{ml}$. of blood was withdrawn by clean venepuncture, with the minimum of venous occlusion, into a siliconized syringe. The blood was immediately transferred to a previously cooled centrifuge-tube, in melting ice, containing $1 \mathrm{ml}$. of $3.8 \%$ sodium citrate. The first sample remained in the melting ice until the second sample was withdrawn, immediately after the exercise, and then both were centrifuged at 3,400 r.p.m. at $+4^{\circ} \mathrm{C}$. for 20 minutes in a refrigerated centrifuge. The upper third of the plasma was transferred, by means of a siliconized pasteur pipette, into a pre-cooled plastic tube ; euglobulin precipitation was performed immediately.

Euglobulin Lysis Time. $-1 \mathrm{ml}$. of plasma was transferred to a siliconized centrifuge-tube in melting ice, containing $19 \mathrm{ml}$. of distilled water and $0.18 \mathrm{ml}$. of $1 \%$ acetic acid. The $p \mathrm{H}$ was finally adjusted to 6.0, on a Beckman Zeromatic $\mathrm{pH}$ meter, $0.25 \%$ acetic acid being used. Precipitation time was 10 minutes from the addition of the plasma and was done in melting ice. The euglobulin suspensions were then centrifuged at 3,400 r.p.m. for 20 minutes at $+4^{\circ} \mathrm{C}$. The supernatant was discarded, the inside of the centrifuge tube wiped dry with a tissue, and the precipitate resuspended in $1 \mathrm{ml}$. of barbiturate buffer $p H$ 7.4. $0.24 \mathrm{ml}$. of this euglobulin solution was transferred, in triplicate, to 3 by $\frac{3}{8}$ in. $(7.5$ by $1-\mathrm{cm}$.) siliconized test-tubes and $0.24 \mathrm{ml}$. of thrombin solution $(5$ units $/ \mathrm{ml}$. in barbiturate buffer $p \mathrm{H}$ 7.4) added immediately. The test-tubes were placed in a water-bath at $37^{\circ} \mathrm{C}$. and the time taken from the addition of thrombin to complete lysis was recorded as the euglobulin lysis time.

Inhibitor Assay.-Inhibitor assays were based on the method of Blix (1964). Human fibrin plates were prepared by a modification of the method of Astrup and Müllertz (1952). $10 \mathrm{ml}$. of $0.15 \mathrm{~g} . / 100 \mathrm{ml}$. human fibrinogen in this buffer were pipetted into a plastic Petri dish, internal diameter $8.8 \mathrm{~cm}$., and before clotting with $0.2 \mathrm{ml}$. of thrombin solution $(50$ units $/ \mathrm{ml}$. in tris buffer) on a level table, $1 \mathrm{ml}$. of euglobulin solution diluted in saline was added and thoroughly mixed. A series of four plates were used containing dilutions of $1 / 10,1 / 25$, and $1 / 50$ and a control with $1 \mathrm{ml}$. of saline. Thence, $0.03-\mathrm{ml}$. drops of urokinase ( $3.0 \mathrm{units} / \mathrm{ml}$. in tris buffer) were placed on to the

TABLE I.-Euglobulin Lysis Time Before and After Moderate Exercise in Male and Female Subjects Aged 18 to 30 Years

\begin{tabular}{|c|c|c|c|c|c|c|c|}
\hline \multirow{3}{*}{$\begin{array}{l}\text { Subject } \\
\text { No. }\end{array}$} & \multicolumn{3}{|c|}{ Males } & \multirow{3}{*}{$\begin{array}{c}\text { Subject } \\
\text { No. }\end{array}$} & \multicolumn{3}{|c|}{ Females } \\
\hline & \multicolumn{3}{|c|}{ Euglobulin Lysis Time } & & \multicolumn{3}{|c|}{ Euglobulin Lysis Time } \\
\hline & Before & After & $\begin{array}{c}\text { Increase } \\
(\%)\end{array}$ & & Before & After & $\begin{array}{c}\text { Increase } \\
(\%)\end{array}$ \\
\hline M 1 & $\begin{array}{l}140 \\
660 \\
500\end{array}$ & $\begin{array}{r}71 \\
332 \\
257\end{array}$ & $\left.\begin{array}{l}49 \\
50 \\
49\end{array}\right\} 49$ & F 1 & $\begin{array}{l}156 \\
228 \\
198\end{array}$ & $\begin{array}{r}71 \\
100 \\
95\end{array}$ & $\left.\begin{array}{l}54 \\
56 \\
52\end{array}\right\} 54$ \\
\hline M 2 & $\begin{array}{l}240 \\
304\end{array}$ & $\begin{array}{l}110 \\
136\end{array}$ & $\left.\begin{array}{l}54 \\
55\end{array}\right\} 55$ & F 2 & $\begin{array}{r}112 \\
113 \\
* 99 \\
97\end{array}$ & $\begin{array}{l}70 \\
75 \\
62 \\
61\end{array}$ & $\left.\begin{array}{l}38 \\
34 \\
37 \\
37\end{array}\right\} 37$ \\
\hline M 3 & $\begin{array}{r}195 \\
105 \\
135 \\
77 \\
83 \\
148\end{array}$ & $\begin{array}{r}120 \\
58 \\
80 \\
45 \\
51 \\
92\end{array}$ & $\left.\begin{array}{l}48 \\
45 \\
40 \\
42 \\
39 \\
38\end{array}\right\} 43$ & F 3 & $\begin{array}{r}115 \\
88 \\
177 \\
* 140\end{array}$ & $\begin{array}{l}55 \\
45 \\
96 \\
74\end{array}$ & $\left.\begin{array}{l}50 \\
49 \\
46 \\
47\end{array}\right\} 48$ \\
\hline M 4 & $\begin{array}{r}620 \\
84 \\
270 \\
318 \\
210\end{array}$ & $\begin{array}{r}440 \\
60 \\
200 \\
213 \\
156\end{array}$ & $\left.\begin{array}{l}29 \\
29 \\
26 \\
33 \\
26\end{array}\right\} 29$ & F 4 & $\begin{array}{l}117 \\
425 \\
120\end{array}$ & $\begin{array}{r}49 \\
117 \\
45\end{array}$ & $\left.\begin{array}{l}58 \\
73 \\
63\end{array}\right\} 65$ \\
\hline M 5 & $\begin{array}{l}61 \\
75 \\
57 \\
65 \\
81\end{array}$ & $\begin{array}{l}35 \\
42 \\
35 \\
45 \\
50\end{array}$ & $\left.\begin{array}{l}43 \\
44 \\
39 \\
31 \\
38\end{array}\right\} 37$ & $F=$ & $\begin{array}{l}160 \\
200\end{array}$ & $\begin{array}{r}83 \\
100\end{array}$ & $\left.\begin{array}{l}48 \\
50\end{array}\right\} 49$ \\
\hline M 6 & $\begin{array}{l}115 \\
146\end{array}$ & $\begin{array}{l}70 \\
96\end{array}$ & $\left.\begin{array}{l}39 \\
34\end{array}\right\} 37$ & F 6 & $\begin{array}{r}222 \\
135 \\
204 \\
* 192 \\
193 \\
143\end{array}$ & $\begin{array}{l}97 \\
71 \\
90 \\
95 \\
97 \\
70\end{array}$ & $\left.\begin{array}{l}56 \\
47 \\
56 \\
51 \\
50 \\
51\end{array}\right\} 52$ \\
\hline M 7 & $\begin{array}{r}105 \\
131 \\
77 \\
76\end{array}$ & $\begin{array}{l}60 \\
78 \\
47 \\
50\end{array}$ & $\left.\begin{array}{l}43 \\
41 \\
39 \\
34\end{array}\right\} 39$ & F 7 & $\begin{array}{r}102 \\
141 \\
90\end{array}$ & $\begin{array}{l}48 \\
65 \\
45\end{array}$ & $\left.\begin{array}{l}53 \\
54 \\
50\end{array}\right\} 52$ \\
\hline M 8 & $\begin{array}{l}550 \\
211 \\
745\end{array}$ & $\begin{array}{l}440 \\
172 \\
505\end{array}$ & $\left.\begin{array}{l}20 \\
19 \\
32\end{array}\right\} 24$ & F 8 & $\begin{array}{l}132 \\
370 \\
300\end{array}$ & $\begin{array}{r}53 \\
134 \\
100\end{array}$ & $\left.\begin{array}{l}60 \\
64 \\
67\end{array}\right\} 64$ \\
\hline M 9 & $\begin{array}{l}143 \\
150 \\
150\end{array}$ & $\begin{array}{l}60 \\
65 \\
62\end{array}$ & $\left.\begin{array}{l}58 \\
57 \\
59\end{array}\right\} 58$ & F 9 & $\begin{array}{r}132 \\
* 135 \\
117 \\
95 \\
\end{array}$ & $\begin{array}{l}57 \\
62 \\
50 \\
45 \\
\end{array}$ & $\left.\begin{array}{l}57 \\
54 \\
47 \\
53\end{array}\right\} 53$ \\
\hline M 10 & $\begin{array}{r}105 \\
95 \\
103 \\
\end{array}$ & $\begin{array}{l}63 \\
59 \\
60 \\
\end{array}$ & $\left.\begin{array}{l}40 \\
38 \\
42\end{array}\right\} 40$ & F 10 & $\begin{array}{l}84 \\
77 \\
80\end{array}$ & $\begin{array}{l}43 \\
42 \\
41\end{array}$ & $\left.\begin{array}{r}49 \\
45 \\
49\end{array}\right\} 48$ \\
\hline M 11 & $\begin{array}{l}255 \\
315 \\
262\end{array}$ & $\begin{array}{l}124 \\
153 \\
129\end{array}$ & $\left.\begin{array}{l}51 \\
51 \\
51\end{array}\right\} 51$ & F 11 & $\begin{array}{r}123 \\
131 \\
* 132 \\
120\end{array}$ & $\begin{array}{l}72 \\
75 \\
74 \\
75\end{array}$ & $\left.\begin{array}{l}42 \\
43 \\
44 \\
38\end{array}\right\} 42$ \\
\hline
\end{tabular}

TABLE I-continued

\begin{tabular}{|c|c|c|c|c|c|c|c|}
\hline \multirow{3}{*}{$\begin{array}{l}\text { Subject } \\
\text { No. }\end{array}$} & \multicolumn{3}{|c|}{ Males } & \multirow{3}{*}{$\begin{array}{c}\text { Subject } \\
\text { No. }\end{array}$} & \multicolumn{3}{|c|}{ Females } \\
\hline & \multicolumn{3}{|c|}{ Euglobulin Lysis Time } & & \multicolumn{3}{|c|}{ Euglobulin Lysis Time } \\
\hline & Before & After & $\begin{array}{c}\text { Increase } \\
(\%)\end{array}$ & & Before & After & $\begin{array}{c}\text { Increase } \\
(\%)\end{array}$ \\
\hline M 12 & $\begin{array}{l}120 \\
159 \\
272 \\
151 \\
245 \\
132\end{array}$ & $\begin{array}{r}95 \\
116 \\
192 \\
106 \\
185 \\
98\end{array}$ & $\left.\begin{array}{l}21 \\
27 \\
29 \\
30 \\
24 \\
26\end{array}\right\} 26$ & F 12 & $\begin{array}{r}132 \\
* 135 \\
145 \\
142\end{array}$ & $\begin{array}{l}62 \\
65 \\
71 \\
62\end{array}$ & $\left.\begin{array}{l}53 \\
52 \\
51 \\
49\end{array}\right\} 51$ \\
\hline M 13 & $\begin{array}{l}494 \\
720 \\
274\end{array}$ & $\begin{array}{l}211 \\
370 \\
137\end{array}$ & $\left.\begin{array}{l}57 \\
48 \\
50\end{array}\right\} 52$ & F 13 & $\begin{array}{l}180 \\
306 \\
250 \\
148\end{array}$ & $\begin{array}{r}92 \\
142 \\
117 \\
71\end{array}$ & $\left.\begin{array}{l}49 \\
54 \\
53 \\
52\end{array}\right\} 52$ \\
\hline M 14 & $\begin{array}{l}100 \\
113 \\
110\end{array}$ & $\begin{array}{l}54 \\
56 \\
52\end{array}$ & $\left.\begin{array}{l}46 \\
50 \\
53\end{array}\right\} 50$ & F 14 & $\begin{array}{r}595 \\
185 \\
90\end{array}$ & $\begin{array}{r}380 \\
110 \\
53\end{array}$ & $\left.\begin{array}{l}36 \\
41 \\
41\end{array}\right\} 39$ \\
\hline M 15 & $\begin{array}{l}112 \\
223 \\
180\end{array}$ & $\begin{array}{r}52 \\
104 \\
80\end{array}$ & $\left.\begin{array}{l}54 \\
53 \\
56\end{array}\right\} 54$ & F 15 & $\begin{array}{r}105 \\
110 \\
100 \\
* 105\end{array}$ & $\begin{array}{l}45 \\
55 \\
50 \\
55\end{array}$ & $\left.\begin{array}{l}57 \\
50 \\
50 \\
48\end{array}\right\} 51$ \\
\hline M 16 & $\begin{array}{l}257 \\
120 \\
140\end{array}$ & $\begin{array}{r}143 \\
80 \\
90\end{array}$ & $\left.\begin{array}{l}44 \\
33 \\
36\end{array}\right\} 38$ & F 16 & $\begin{array}{l}115 \\
138 \\
171\end{array}$ & $\begin{array}{r}95 \\
81 \\
101\end{array}$ & $\left.\begin{array}{l}48 \\
41 \\
41\end{array}\right\} 43$ \\
\hline M 17 & $\begin{array}{r}72 \\
108 \\
200 \\
320\end{array}$ & $\begin{array}{r}65 \\
86 \\
184 \\
310 \\
\end{array}$ & $\left.\begin{array}{r}10 \\
20 \\
8 \\
3\end{array}\right\} 10$ & F 17 & $\begin{array}{r}150 \\
198 \\
* 178 \\
178 \\
\end{array}$ & $\begin{array}{l}76 \\
93 \\
87 \\
95 \\
\end{array}$ & $\left.\begin{array}{l}49 \\
51 \\
45 \\
41\end{array}\right\} 47$ \\
\hline M 18 & $\begin{array}{l}189 \\
270\end{array}$ & $\begin{array}{r}99 \\
137\end{array}$ & $\left.\begin{array}{l}48\} 49 \\
49\end{array}\right\} 49$ & F 18 & $\begin{array}{l}166 \\
176 \\
162 \\
\end{array}$ & $\begin{array}{r}85 \\
104 \\
95 \\
\end{array}$ & $\left.\begin{array}{l}49 \\
41 \\
42\end{array}\right\} 44$ \\
\hline M 19 & $\begin{array}{l}65 \\
84 \\
94\end{array}$ & $\begin{array}{l}51 \\
56 \\
64\end{array}$ & $\left.\begin{array}{l}22 \\
33 \\
32\end{array}\right\} 29$ & F 19 & $\begin{array}{l}176 \\
202 \\
200 \\
\end{array}$ & $\begin{array}{l}103 \\
124 \\
120\end{array}$ & $\left.\begin{array}{l}42 \\
39 \\
40\end{array}\right\} 40$ \\
\hline M 20 & $\begin{array}{l}250 \\
230\end{array}$ & $\begin{array}{l}160 \\
150\end{array}$ & $\left.\begin{array}{l}36 \\
35\end{array}\right\} 36$ & F 20 & $\begin{array}{l}121 \\
131 \\
117\end{array}$ & $\begin{array}{l}68 \\
73 \\
65\end{array}$ & $\left.\begin{array}{l}43 \\
44 \\
44\end{array}\right\} 44$ \\
\hline M 21 & $\begin{array}{l}116 \\
108 \\
110\end{array}$ & $\begin{array}{l}87 \\
82 \\
85\end{array}$ & $\left.\begin{array}{l}25 \\
24 \\
23\end{array}\right\} 24$ & F 21 & $\begin{array}{r}68 \\
80 \\
* 82 \\
89 \\
\end{array}$ & $\begin{array}{l}30 \\
33 \\
32 \\
39 \\
\end{array}$ & $\left.\begin{array}{l}56 \\
59 \\
56 \\
54\end{array}\right\} 56$ \\
\hline M 22 & $\begin{array}{l}120 \\
500\end{array}$ & $\begin{array}{r}75 \\
300\end{array}$ & $\left.\begin{array}{l}38 \\
40\end{array}\right\} 39$ & F 22 & $\begin{array}{r}90 \\
105 \\
112 \\
\end{array}$ & $\begin{array}{l}45 \\
53 \\
58 \\
\end{array}$ & $\left.\begin{array}{l}50 \\
50 \\
49\end{array}\right\} 50$ \\
\hline M 23 & $\begin{array}{l}174 \\
135 \\
100 \\
\end{array}$ & $\begin{array}{l}89 \\
77 \\
60 \\
\end{array}$ & $\left.\begin{array}{l}49 \\
43 \\
40\end{array}\right\} 44$ & F 23 & $\begin{array}{l}115 \\
107\end{array}$ & $\begin{array}{l}60 \\
60\end{array}$ & $\left.\begin{array}{l}48 \\
44\end{array}\right\} 46$ \\
\hline M 24 & $\begin{array}{l}539 \\
269\end{array}$ & $\begin{array}{l}324 \\
162\end{array}$ & $\left.\begin{array}{l}40 \\
40\end{array}\right\} 40$ & F 24 & $\begin{array}{r}99 \\
96 \\
110 \\
\end{array}$ & $\begin{array}{l}52 \\
56 \\
61 \\
\end{array}$ & $\left.\begin{array}{l}47 \\
42 \\
45\end{array}\right\} 45$ \\
\hline M 25 & $\begin{array}{r}107 \\
76 \\
95\end{array}$ & $\begin{array}{l}63 \\
45 \\
60\end{array}$ & $\left.\begin{array}{l}42 \\
41 \\
37\end{array}\right\} 40$ & F 25 & $\begin{array}{l}118 \\
120\end{array}$ & $\begin{array}{l}73 \\
74\end{array}$ & $\left.\begin{array}{l}38 \\
38\end{array}\right\} 38$ \\
\hline
\end{tabular}


fibrin film in triplicate 20 minutes after clotting. The plates were incubated at $37^{\circ} \mathrm{C}$. for 24 hours and the product of the perpendicular diameters taken as a measure of fibrinolytic activity.

Fibrinogen Assay.-The method of Ratnoff and Menzie (1951), as modified by Alkjaersig (1960), was used.

Plasminogen Assay.-The caseinolytic assay of Remmert and Cohen (1949), as modified by Alkjaersig et al. (1959), was used.

\section{Results}

Resting Levels of Euglobulin Lysis Time.-Table I shows the results in detail of all experiments. The resting level of plasminogen activator, as measured by the euglobulin lysis time, varied from subject to subject and from day to day in the same subject. This-variation could not be correlated with the euglobulin fibrinogen and plasminogen on the 34 occasions they were assayed (Fig. 1). No urokinase inhibitor was demonstrated in the euglobulin solutions. The females had a lower euglobulin lysis time than the men, which was highly significant $(\mathbf{P}<0.001)$. There were no significant changes related to the phases during the menstrual cycle in the nine females studied.

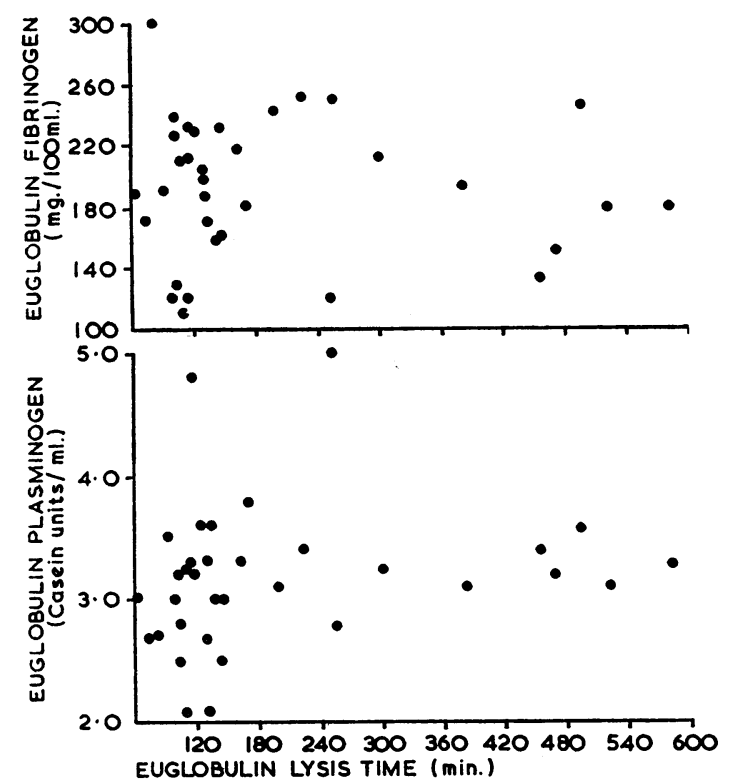

FIG. 1.-Euglobulin plasminogen and fibrinogen plotted against the euglobulin lysis time.

Fibrinolytic Response to Moderate Exercise.-If A and B represent the resting and post-exercise euglobulin lysis times, respectively, then the percentage increase following exercise was calculated as $\mathrm{A}-\mathrm{B} / \mathrm{A} \times 100$. The results of this calculation are shown in Table I for each experiment, and also the mean percentage response for each individual. The results indicated that, for any one subject, the fibrinolytic response was reproducible (correlation coefficient $(r)=0.9929$ and $\mathrm{P}<0.001$ ). Furthermore, there was a highly significant individual variation in response (analysis of variance showed $F=36.7$, which was significant at the $1 \%$ level).

Table II shows the frequency distribution of the percentage response in all the subjects and that the females produced a

TABLE II.-Frequency Distribution of Percentage Response to Moderate \begin{tabular}{c} 
Exercise \\
\hline
\end{tabular}

\begin{tabular}{cc|c|c|c|c|c|c}
\hline & & \multicolumn{6}{|c}{ Percentage Response } \\
\cline { 2 - 7 } & & $11-20$ & $21-30$ & $31-40$ & $41-50$ & $51-60$ & $61-70$ \\
\hline Males .. & $\cdots$ & 1 & 5 & 9 & 5 & 5 & 0 \\
Females & $\cdots$ & 0 & 0 & 4 & 11 & 8 & 2 \\
\hline Total & $\cdots$ & 1 & 5 & 13 & 16 & 13 & 2 \\
\hline
\end{tabular}

significantly greater fibrinolytic response than the males $(\mathbf{P}<0.01)$. The individual variation in fibrinolytic response did not correlate with the pulse rate increase following exercise in the 22 subjects studied (Fig. 2). There was, however, a highly significant greater mean pulse-rate response in the female subjects (males 70 min., females 84 min., $\mathrm{P}<0.001$ ). There appeared to be no significant changes in the fibrinolytic response to moderate exercise throughout a menstrual cycle.

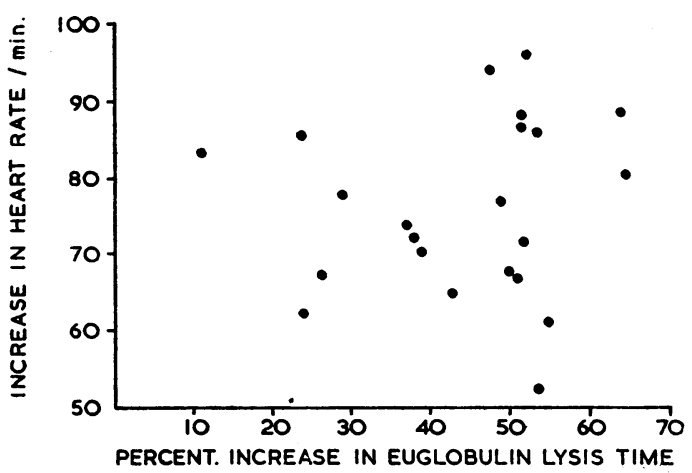

FIg. 2.-Percentage increase in euglobulin lysis time plotted against increase in heart rate following moderate exercise.

\section{Discussion}

We have confirmed the findings of Blix (1961) that, even under carefully standardized assay procedures, the resting euglobulin lysis time varied from subject to subject and from day to day in the same subject. Despite the criticism of substrate variability, the euglobulin lysis time has been shown to be a good measure of plasminogen activator (Sawyer et al., 1960 ; Iatridis and Ferguson, 1963 ; Fletcher et al., 1964). We were unable to attribute the daily fluctuations in the euglobulin lysis time to the changes in euglobulin fibrinogen and plasminogen, nor was there evidence of a urokinase inhibitor in those euglobulin fractions giving a long lysis time. Although this problem is under investigation in this laboratory, we feel there is, as yet, insufficient evidence to exclude the possibility that the daily resting level of circulating plasminogen activator may vary in any one individual. Furthermore, it would appear, as suggested by Fearnley (1961), using the dilute blood-clot-assay technique, that this daily fluctuation is more pronounced in some individuals than in others.

The finding of a significant sex difference in the resting euglobulin lysis time is contrary to the observations of Beller et al. (1964) and Brakman et al. (1966). We are not able to explain this apparent discrepancy, but it may be relevant that previous conclusions have been reached, in the main, from single observations. We have confirmed, however, that the daily fluctuations in the resting euglobulin lysis time do not appear to be related to the menstrual cycle.

Despite this daily fluctuation, the level following a standard exercise procedure, in the same subject, appeared to be related in a constant way. Thus the fibrinolytic response (which we have termed "fibrinolytic reactivity") to a fixed moderate exercise procedure, expressed as a percentage of the pre-exercise level, in normal young subjects, is a reproducible phenomenon. There seems to be individual variation and there exists a small but definite group of poor responders. Of no less interest was the finding that women of the same age-group seem to have a greater fibrinolytic reactivity than men, and that in the group studied no female poor responders were discovered. There appeared to be no significant change in fibrinolytic reactivity during the menstrual cycle.

It is possible that the variation in fibrinolytic response may simply mirror the individual variation in stress to a standard exercise procedure. If pulse-rate response is a measure of the exercise stress, then the absence of a correlation, within each 
sex group, would not confirm this view. When the two sex groups are compared, however, the position is less clear. The females showed a significantly higher pulse response than the males. This finding is in agreement with the work of Astrand (1952), who suggested that the cause might be a stronger distaste in women for physical exertion, or that men may be more efficient working machines.

Severe exercise has been shown to increase body temperature (Holmgren and McIlroy, 1964) and severe heat stress increases plasma fibrinolytic activity (Bedrak et al., 1963). Although at present we have no data which might elucidate this possible explanation of our results, we feel it unlikely that the moderate exercise procedure used was sufficient to produce significant changes in core temperature, which in turn would cause an increased plasma fibrinolysis.

We have been unable to explain our group of poor responders on the basis of physical fitness (Biggs et al., 1947). Four of our volunteers were highly trained athletes and their mean response ranged from $24 \%$ to $54 \%$. Iatridis and Ferguson (1963) demonstrated the generation of a fibrinolytic inhibitor following exercise in one of their poor responders. We have been unable to detect an increase in urokinase inhibitor content of our postexercise euglobulin solutions, or in any euglobulin fractions precipitated at $\mathrm{pH} 6$.

The significance of the fibrinolytic reactivity to exercise remains, as yet, unknown. We postulate that it may represent, in part, the ability of the individual to generate circulating plasminogen activator to stress. Exercise has also been shown to increase the coagulability of the blood (Vuori, 1950 ; Bond et al., 1961 ; Iatridis and Ferguson, 1963 ; Burt et al., 1964 ; von Kaulla and von Kaulla, 1964). Thus, on the basis of a dynamic equilibrium between coagulation and fibrinolysis, an increase in fibrinolysis would be anticipated. Iatridis and Ferguson (1963), however, observed that 11 of their 59 subjects failed to increase their circulating plasminogen activator following strenuous exercise despite an apparent increase in coagulability. Burt et al. (1964), in a study of coagulation and fibrinolysis following strenuous exercise, concluded that the mean changes were in favour of fibrinolysis. Examination of their results in more detail, however, shows that two of their 44 subjects gave a poor fibrinolytic response, whereas the coagulation changes in these subjects were similar to those in some of the subjects giving a marked fibrinolytic response.

Hypercoagulability and increased fibrinolysis have also been demonstrated during anxiety (Ogston et al., 1962 ; Patsch, 1963). We postulate, therefore, that the possibility now arises that persons with a poor fibrinolytic reactivity may be subject to transitory episodes of coagulation-fibrinolysis disequilibrium during their day-to-day living. The disequilibrium might arise from either an exaggerated increase in coagulation associated with a normal increase in fibrinolysis, or vice versa. In the light of Astrup's hypothesis these persons may be at risk to atherosclerosis and/or thrombosis.

Evidence supporting this view is fragmentary. Cirrhotic patients have a low incidence of myocardial infarction (Grant et al., 1959 ; Howell and Manion, 1960), and it has been shown that they may possess exaggerated fibrinolytic reactivity (Weiner, 1963 ; Fletcher et al., 1964) as well as a general tendency to hypocoagulation (Ollendorff et al., 1966). von Kaulla and von Kaulla (1964) have provided suggestive evidence that patients with a proved history of myocardial infarction may show an exaggerated hypercoagulability after exercise.

There is reason to believe that atherosclerosis may be prevalent in young males (Thomas, 1957 ; Holman et al., 1958) and that women, during the reproductive period of their lives, are relatively immune (Thomas, 1957 ; Strong and McGill, 1962). Our findings of a small group of apparently normal young men with poor fibrinolytic reactivity to moderate exercise, and that women of the same age-group have a greater fibrinolytic reactivity, may therefore prove to be of some interest.
We believe that the study of coagulation and fibrinolysis, simultaneously, before and after exercise may prove to be a more relevant focusing-point for observing potential states of coagulation-fibrinolysis disequilibrium than a measurement of these values in the resting state, as has been the practice in the past (Hume, 1958 ; Lackner and Merskey, 1960 ; Nestel, 1960 ; Ogston, 1962 ; Katz et al., 1963 ; Naimi et al., 1963 ; MacKay and Hume, 1964 ; Chakrabarti et al., 1966).

\section{Summary}

The euglobulin lysis time before and after moderate exercise has been studied in 25 male and 25 female normal subjects aged 18 to 30 years. The resting euglobulin lysis time varied from subject to subject and from day to day in the same subject. A highly significant lower level was found in the females. There was no correlation in the resting levels of euglobulin lysis time with the menstrual cycle.

The fibrinolytic reactivity to moderate exercise was reproducible in any one individual, but there was a significant difference in reactivity between individuals, which revealed the presence of a group of consistently poor reactors. The fibrinolytic reactivity in women of the same age-group was significantly greater than that in men, but there appeared to be no changes coincident with the phases of the menstrual cycle.

The possible significance of these findings is discussed in the light of Astrup's hypothesis of the aetiology of atherosclerosis and/or thrombosis.

I wish to thank the many volunteers; Mr. A. G. E. Allan for invaluable technical assistance; Dr. R. A. Cumming, Director of the South-East Scotland Regional Blood Transfusion Centre, for providing the laboratory facilities; and Professor K. W. Donald, university department of medicine, for the generous provision of treadmill facilities. This research programme has been supported by a grant from the Scottish Hospital Endowments Research Trust.

\section{REFERENCES}

Alkjaersig, N. (1960). Proceedings of the Conference on Thrombolytic Agents, 8-9 April 1960, edited by H. R. Roberts and J. D. Geraty, p. 136. Haematology Study Section (U.S.) Public Health Service. Fletcher, A. P., and Sherry, S. (1959). f. clin. Invest., 38, 1086. Asstrand, P.-O. (1952). Experimental Studies of Working Capacities in Relation to Sex and Age. Munksgaard, Copenhagen.

Astrup, T. (1956). Lancet, 2, 565.

- and Müllertz, S. (1952). Arch. Biochem., 40, 346.

Bedrak, E., Beer, G., and Furman, K. I. (1963). Israel f. exp. Med.,

Beller, F. K., Goebelsmann, U., Douglas, G. W., and Johnson, A. (1964). Obstet. and Gynec., 23, 12.

Biggs, R., Macfarlane, R. G., and Pilling, J. (1947). Lancet, 1, 402.

Billimoria, J. D., Drysdale, J., James, D. C. O., and Maclagan, N. F. (1959). Ibid., 2, 471.

Blix, S. (1961). Scand. ₹. clin. Lab. Invest., 13, Suppl. No. 58, p. 3 (1964). Ibid., 16, 403.

Blombäck, B., and Blombäck, M. (1957). Ark. Kemi, 10, 415.

Bond, T. P., Celander, D. R., and Guest, M. M. (1961). Fed. Proc., $20,56$.

Brakman, P., Albrechtsen, O. K., and Astrup, T. (1966). Brit. ₹. Haemat., 12, 74.

Burt, J. J., Blyth, C. S., and Rierson, H. A. (1964). ₹. Sport. Med. (Torino), 4, 213.

Chakrabarti, R., Fearnley, G. R., Hocking, E. D., Delitheos, A., and Clark, G. M. (1966). Lancet, 1, 573.

Fearnley, G. R. (1961). Ibid., 1, 506

and Lackner, R. (1955). Brit. F. Haemat., 1, 189.

etcher, A. P., Biederman, O., Moore, D., Alkjaersig, N., and Sherry, S. (1964). f. clin. Invest., 43, 681.

Grant, W. C., Waserman, F., Rodensky, P. L., and Thomson, R. V. (1959). Ann. intern. Med., 51, 774.

Holman, R. L., McGill, H. C., Strong, J. P., and Geer, J. C. (1958). Amer. F. Path., 34, 209.

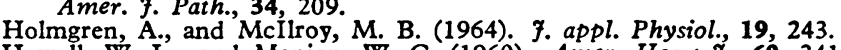

Howell, W. L., and Manion, W. C. (1960). Amer. Heart $\mathcal{f} ., 60,341$.

Hume, R. (1958). Brit. Heart f., 20, 15.

Iatridis, S. G., and Ferguson, J.. H. (1963). F. appl. Physiol., 18, 337.

Jang, E., Fletcher, B. T.. and Bickford, A. F. (1964). Clin. Sci., 27, 9.

Katz, A. M., McDonald, L., Davies, B., and Edgill, M. (1963). Lancet, 1,801 .

von Kaulla, K. N., and von Kaulla, E. (1964). Circulat. Res., 14, 436.

Lackner, H., and Merskey, C. (1960). Brit. F. Haemat., 6, 402.

MacKay, N., and Hume, R. (1964). Scot. med. ₹., 9, 359.

Naimi, S., Goldstein, R., and Proger, S. (1963). Circulation, 27, 904. 
Vestel, P. J. (1960). Aust. Ann. Med., 9, 234

Ogston, D. (1962). Brit. med. F., 1, 1242 .

and Fullerton, H. W. (1961). Lancet, 2, 730.

and McAndrew, G. M. (1964). Ibid., 2, 1205.

McDonald, G. A., and Fullerton, H. W. (1962). Ibid., 2, 521.

Ollendorff, P., Rasmussen, J., and Astrup, T. (1966). Acta med. scand. 179, 101 .

Owren, P. A. (1947). Ibid., Suppl. No. 194

Patsch, J. (1963). Wien. med. Wschr., 113, 537.

Ratnoff, O. D., and Menzie, C. (1951), F. Lab. clin. Med., 37, 316.
Remmert, L. F., and Cohen, P. P. (1949), f. biol. Chem., 181, 431

Sawyer, W. D., Fletcher, A. P. Alkjaersig, N., and Sherry, S. (1960). F. clin. Invest., 39, 426 .

Sherry, S., Lindemeyer, R. I., Fletcher, A. P., and Alkjaersig, N. (1959). Ibid., 38, 810 .

Strong, J. P., and McGill, H. C. (19662). Amer. F. Path., 40, 37.

Thomas, W. A. (1957). Nutr. Rev., 15, 97.

Truelove, S. C. (1951). Clin. Sci., 10, 229.

Vuori (1950). Acta med. scand., 236, 296.

Weiner, M. (1963). Amer. F. med. Sci., 246, 294.

\section{Medical Memoranda}

\section{Liver Damage and Impaired Glucose Tolerance after Paracetamol Overdosage}

\author{
Brit. med. F., 1966, 2, 506-507
}

Paracetamol is a widely used and comparatively safe antipyretic analgesic (Brit. med. F., 1965 ; Drug and Therapeutics Bulletin, 1966). In view of its increasing clinical use, the following case history is of interest.

\section{CASe History}

A 54-year-old man weighing 7 st. $10 \mathrm{lb}$. (49 kg.) was admitted io the casualty ward at Woolmanhill, Aberdeen, on 11 September 1965, within two hours of consuming a bottle of beer and a number of paracetamol tablets, estimated at 70 by his wife. $\mathrm{He}$ had been taking the drug over a period of two years for low back pain of undetermined origin. There was nothing else of note in his past medical history, and, in particular, no history of liver disease or alcoholism. His mother was known to have had diabetes.

On admission he was drowsy, but no abnormal physical signs were elicited. The pulse rate was $78 / \mathrm{min}$. and the blood-pressure $100 / 70 \mathrm{~mm} . \mathrm{Hg}$; the extremities were warm. The stomach was washed out, and the aspirate was reported to contain a "small amount of paracetamol." The serum concentration of paracetamol on admission was $76 \mathrm{mg} . / 100 \mathrm{ml}$.

As the patient was cooperative, treatment was started with forced oral fluids. A urine sample obtained three hours after admission contained $2 \%$ glucose, but was otherwise normal. Over the next 12 hours the glycosuria continued, and as his general condition was deteriorating he was transferred to Woodend General Hospital on 12 September. On arrival he was lethargic but aggressive when disturbed, was incontinent of urine and faeces, and complained of blindness. He lay with his eyes deviated to the right, and horizontal nystagmus was present. From lack of cooperation full assessment of the nature and extent of the visual defect was not possible. No other abnormalities were found on physical examination. The pulse rate was now $110 /$ minute and the blood-pressure $150 / 100 \mathrm{~mm}$. $\mathrm{Hg}$.

Investigations on 12 September showed: urine-glucose $1 \%$, no acetone, bile, or urobilinogen ; serum urea $20 \mathrm{mg} . / 100 \mathrm{ml}$., blood sugar $146 \mathrm{mg} . / 100 \mathrm{ml}$. (glucose oxidase method); haemoglobin 13.7 g. $/ 100$ ml., W.B.C. $8,200 /$ c.mm., and E.S.R. $3 \mathrm{~mm} . /$ hour (Westergren).

On 13 September an oral glucose-tolerance test with $50 \mathrm{~g}$. of glucose was abnormal, with a fasting blood-sugar level of 106 mg./100 ml., rising to $276 \mathrm{mg} . / 100 \mathrm{ml}$. at one hour and falling to $184 \mathrm{mg} . / 100 \mathrm{ml}$. at two hours (see Chart, curve 1). A 2,000calorie diet containing $200 \mathrm{~g}$. of carbohydrate was therefore started on 14 September together with $100 \mathrm{mg}$. of chlorpropamide daily. With no other treatment his general condition improved, there was no further glycosuria, and his vision returned to normal.

On 17 September he was noticed to be icteric, and although the liver was not enlarged clinically, he complained of upper abdominal pain.
Investigations showed: - urine: bilirubin ++ , urobilinogen +++ , no glucose or acetone; serum: bilirubin $4.4 \mathrm{mg} . / 100 \mathrm{ml}$., Van den Bergh + , glutamic oxaloacetic transaminase (S.G.O.T.) 216 units, glutamic pyruvic transaminase (S.G.P.T.) 124 units, sodium 137, potassium 3.7, chloride $96, \mathrm{CO}_{2} 26.5 \mathrm{mEq} / 1$, alkaline phosphatase 19 King-Armstrong units, proteins normal, urea $59 \mathrm{mg} .100 \mathrm{ml}$., and fasting blood sugar $90 \mathrm{mg} . / 100 \mathrm{ml}$.

Over the next four days the jaundice gradually faded and by 4 October the serum alkaline phosphatase was 11 units, the S.G.O.T. 46 units, and the S.P.G.T. 51 units. A repeat oral glucose-tolerance test showed considerable improvement (Chart, curve 2). The chlorpropamide was discontinued on 8 October, and a normal ward diet introduced on 16 October with no recurrence of the glycosuria. A third glucose-tolerance test on 28 October was normal (Chart, curve 3). Apart from persisting back pain which necessitated his transfer to an orthopaedic ward, his progress thereafter was uneventful.

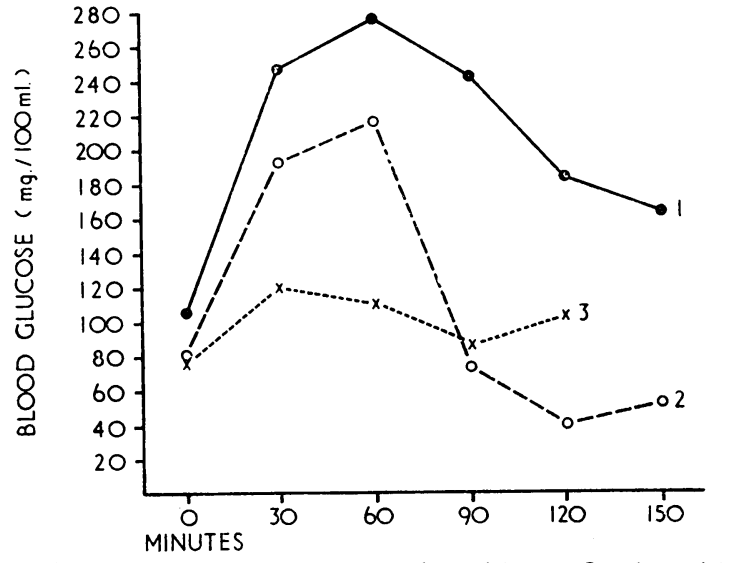

Glucose-tolerance tests on 13 September (1), 4 October (2), and 28 October 1965 (3).

\section{COMMENT}

The remarkable lack of reported side-effects of paracetamol suggests that it is comparatively safe when used in normal therapeutic doses. There is no doubt that this patient had taken and absorbed a large quantity of the drug. The high serum concentration of $76 \mathrm{mg}$. $/ 100 \mathrm{ml}$. is compatible with the estimated intake of 70 tablets $(35 \mathrm{~g}$.), as after ingestion of $2 \mathrm{~g}$. of paracetamol, serum concentrations of up to $5 \mathrm{mg} . / 100 \mathrm{ml}$. may be expected in normal subjects (Prescott and Conney, unpublished data).

Apart from the blindness (which we cannot explain), the presenting clinical features were unremarkable. It was not until six days after the paracetamol was taken that jaundice appeared ; and had it not been for the initial finding of glycosuria the patient might well have been discharged home on the second or third day with the liver damage unrecognized. The results of the liver-function tests suggest hepatocellular damage rather 